\title{
Application of bokashi organic fertilizer in production oflettuce (Lactuca sativa)
}

\begin{abstract}
The use of organic fertilizers formulated and enhanced with microorganisms such as Bokashi fertilizer, which has the ability to modify the soil by balancing its nutritional and functional properties, however, over-application can generate irregularities and alteration of production.This organic fertilizer is presented as an excellent option for the organic production of lettuce (Lactuca sativa) since they provide a gradual release of nutrients and reduce the loss of their bioactive compounds. In addition, the use of conventional fertilizers can easily cause acidification and salinization of the soil, which in the long-run damages production, therefore, the use of chemical-free organic fertilizers results in better metabolic and physiological development, as well as high-quality crops, which allows their use to be highly viable in the production of postharvest lettuces.
\end{abstract}

Keywords: organic fertilizer, bioactive compounds, physiological development, postharvest lettuces
Volume 4 Issue 5 - 2020

\author{
Jonathan dos Santos Viana,' Cesar Augusto \\ Roque Borda, ${ }^{2}$ Luiz Fabiano Palaretti' \\ 'Department of Engineering and Exact Sciences, Júlio de \\ Mesquita Filho School of Agrarian Sciences, Brazil \\ 2Department of Zootechnics, Júlio de Mesquita Filho School of \\ Agrarian Sciences, Brazil
}

Correspondence: Jonathan dos Santos Viana, Department of Engineering and Exact Sciences, Júlio de Mesquita Filho School of Agrarian Sciences, FCAV Jaboticabal - São Paulo, Brazil, Tel 55 98982752059 , Fax (16) 3209-7100,

Email Jonathan_santu@hotmail.com

Received: October 01, 2020 | Published: October 12, 2020

\section{Introduction}

Lettuce (Lactuca sativa L.) is a widely consumed, profitable, easy-to-handleand high nutrient oilplant, being paramount for human health. It develops well in light soils with good fertility and responds satisfactorily to organic fertilization.

Due to the increased costs of mineral fertilization and its direct relationship with the environment, the demand for healthy foods has prompted the development of organic production, which is characterized by the non-use of synthetic inputs and free of chemicals, in addition to using sustainable production systems such as biological control, crop rotation, use of green fertilizers and organic fertilizers. Studies with the use of fungal communities have shown a beneficial effect on the productivity of Lactuca sativa crops, as well as producing a plant without making the use of mineral fertilizers, reducing costs.

The use of organic materials is widely advantageous, as it directly improves the chemical, physical and biological conditions of the soil and raises the level of fertility, making nutrients easily available to plants. These compounds provide gradual release of nutrients, having less loss to the environment. Among this diversity of organic fertilizers is bokashi.
The use of organic compounds is advantageous, because it directly improves the chemical-physical conditions of the soil and increases the level of productive fertility. These compounds provide a gradual release of nutrients, for their best use. Conventional fertilizers easily cause acidification and salinization of the soil, which in the long term damages production and profitability, therefore, the use of chemicalfree organic fertilizers helps improve the development and quality of vegetables such as lettuce. (Lactuca sativa) postharvest. Bokashi organic fertilizer is a positive option for the organic production of lettuce (Lactuca sativa), which is a product based on the anaerobic fermentation of microorganisms added to low-cost bioproducts such as bran, manure or straw, which transform soil organic matter into nutrients that can be used by plants, as well as recover non-productive areas. ${ }^{1}$ Several studies have shown significant increases with the use of Bokashi in the quality, production and yield of vegetables, stimulating the physiological and morphological development of these plants. ${ }^{2}$

The most important action of this organic compound is the biomass fermentation process, rapidly providing favorable conditions for the multiplication of the beneficial microbiota existing in the soil such as: fungi, mycorrhizae and nitrogen fixers, which are part of plant nutrition and of the management of the physical-chemical environment of the soil (Table 1$){ }^{3}$

Table I Values of $\mathrm{pH}$, electrical conductivity (EC), $\mathrm{C}$ and $\mathrm{N}$ contents, $\mathrm{C}: \mathrm{N}$ ratio and the contents of $\mathrm{Ca}, \mathrm{Mg}, \mathrm{K}$ and $\mathrm{P}$ of plant residues used for formulation of fermented organic fertilizer of bokashi type

\begin{tabular}{llllllllll}
\hline & $\mathbf{P}_{\mathbf{H}}$ & $\mathbf{C E}$ & $\mathbf{C}$ & $\mathbf{N}$ & $\mathbf{C : N}$ & $\mathbf{C a}$ & $\mathbf{M g}$ & $\mathbf{K}$ & $\mathbf{P}$ \\
\cline { 2 - 11 } & \multicolumn{2}{l}{ dS.m-I } & $\%$ & & \multicolumn{7}{c}{ (g.kg-1) } \\
\hline Cake de Ricinus communis & 5,67 & 2,01 & 48,25 & 5,77 & 8,45 & 6,63 & 6,10 & 8,50 & 2,26 \\
Gliricidiasepium & 6,06 & 3,07 & 50,76 & 3,95 & 12,85 & 16,93 & 4,78 & 17,50 & 2,20 \\
Saccharumofficinarum bagasse & 6,28 & 0,53 & 53,25 & 0,36 & 147,91 & 2,37 & 0,46 & 2,13 & 0,49 \\
Pennisetumpurpureum & 6,32 & 1,53 & 54,47 & 0,98 & 55,58 & 4,33 & 3,85 & 10,63 & 1,19 \\
Triticum ssp. bran & 6,26 & 1,42 & 55,62 & 2,54 & 21,90 & 0,84 & 2,88 & 8,88 & 2,20 \\
\hline
\end{tabular}


Applying doses of Bokashi on lettuce, significant gains were found in the number of leaves compared to mineral fertilization and biodiesel co-products, the primary factor being the gradual release of nutrients, ${ }^{4}$ and with totally viable ecological production. ${ }^{5}$ Another study evaluated the effect of the application of Bokashi, bovine manure and their combination, on the growth and productivity of nine cultivars of Lactuca sativa in Seropédica - RJ, the results showed that the organic compound at a dose of $0.5 \mathrm{kgm}^{-2}$ were those that provided the highest rates of the evaluated parameters, ${ }^{6}$ as well as two other varieties, "Americana" and "Crespa".

The use of bokashi doses in addition to directly influencing the agronomic performance of lettuce in tropical climate regions can also substantially affect the postharvest quality of the crop.

Quality factors are imperative in the current trend for the distribution of these products in supermarkets and retail chains, which present high requirements and application of strict quality controls. ${ }^{8}$

Post-harvest quality can be seen from organic production as an increase in plant characteristics. The use of bokashi stands out in this function because it increases the amount of leaves, the biomass of the plant and the amount of nutrients of the plant, even when compared to other organic fertilizers ${ }^{9}$ increasing in the greater absorption of nutrients gradually. The $\mathrm{pH}$ of the organic product bokashi can also be considered very good, since it does not interfere in the physiological activities of the plant, ${ }^{10}$ but depending on the doses used it can alter postharvest physical-chemical characteristics such as: $\mathrm{pH}$, total titratable acidity, ash, dry matter and moisture of the crop.

In Brazil, there is a need for further research on bokashi doses to be used, appropriate to the different cultivars, regions and planting times. In addition, in the anxiety of obtaining higher productivity, the olericultor applies in excess, mineral elements, often resulting in nutritional disorders in plants, besides resulting in an increase in the cost of productivity not obtaining.

\section{Conclusion}

Despite the problems caused by the exacerbated use of chemical fertilizers to the soil, the use of organic fertilizers rich in essential nutrients plants are são stilllittleexplored.

The use of bokashi is feasible for the production and cultivation oflettuce (Lactuca sativa), as it directly influences the morphological, physiological or post-harvest characteristics of lettuce crop in a protected environment. It is necessary to identify the effects of bokashi doses as a way to understand how normal plant growth and development can be affected, serving as aguide when the first signs of nutritional deficienceisums are present.
In addition, this information is fundamental because with the development of new processes involving the use of organic fertilizers with lower prices will be the most valued in the foodindustry, in addition to avoiding contamination to the soil.

\section{Acknowledgments}

None.

\section{Conflicts of interest}

Authors declare no conflict of interest exists.

\section{References}

1. Ferreira S, De Souza RJ, Gomes LAA. Produtividade de brocolis de verão com different doses de bokashi. Revista Agrogeoambiental. $2013 ; 5(2)$.

2. Xavier MCG, Santos CA, Costa ESP, et al. Produtividade de repolho em função de doses de bokashi. Journal of neotropical agriculture. 2019;6(1):17-22.

3. Siqueira APP, Siqueira MFB. Bokashi: fermented organic fertilizer. Niterói: Rio Rural Program, 2013.

4. Souza IP. Organic fertilization of lettuce with biodiesel co-products Dissertation (Master in Agronomy) - Federal University of Lavras, Lavras. 2008:42.

5. Souza LH, Campina V, Almeida D, et al. Bokashi doses in the organic production of curly lettuce. Technical scientific congress of engineering and agronomy CONTECC'2016 Rafain Palace Hotel \& Convention Center- Foz do Iguaçu, PR. 2016.

6. Goulart RGT, Santos CA, Oliveira CM, et al. Agronomic performance of lettuce cultivars under organic fertilization in Seropédica, RJ. Revista Brasileira De Agropecuária Sustentável. 2018:8(3).

7. Pinto LP, Korber AHC, Neiverth A, et al. Application of different doses of bokashi-type organic fertilizer in two varieties of lettuce Lactuca sativa L. Challenges - Revista Interdisciplinar da Universidade Federal Do Tocantins. 2017;4(4): 110-116.

8. Cortez LAB, Honorio SL, Moretti CL. Cooling of fruits and vegetables Brasilia, Embrapa. 2002:170.

9. Goulart RGT, Santos CA, Oliveira CM, et al. Agronomic performance of lettuce cultivars under organic fertilization in Seropédica, RJ. Brazilian Magazine of Sustainable Agriculture. 2018:8(3).

10. Magrini FA, Venturin L, Sartori VC. Microbiological evaluation, $\mathrm{pH}$ and humidity of different maturation stages of Biofertilizer Bokashi. Brazilian Journal of Agroecology. 2009:4(2). 